Unity Journal

Vol. III, 65-81, 2022

Doi: https://doi.org/10.3126/unityj.v3i01.43316

Prithvi Narayan Shah Research Center

Directorate General of Military Training, Nepali Army

Kathmandu, Nepal

\title{
The Relation between Foreign Direct Investment Inflows and Tourism Development in Nepal
}

\section{Lokraj Bhandari}

\begin{abstract}
Natural beauty and cultural institutions are perennial factors for tourism development with a competitive advantage in Nepal. However, the country has not been able to capitalize on those natural and cultural resources for the benefit of the people at a large scale. Without in-depth research on the prospect of the tourism industry and its application, Nepal has been lagging behind many of the countries of the world even in the twenty-first century. Nevertheless, existing scholarship on the relation between 'FDI (Foreign Direct Investment) inflows' and 'tourism development', has remained incomplete. Therefore, this study has set the specific objectives of finding and analyzing the causal relationship between these two variables using the time series data of Nepal from 1995 to 2019. It has followed the causalcomparative research design to meet the objectives asserting the dependent variable: 'net FDI inflow' and independent variable: 'tourism development', first. Then, the discourse has forwarded interchanging the dependent into independent and independent into dependent one. This analysis finds a bidirectional relationship between FDI inflow and tourism development in the short run. The arrival of one international tourist causes
\end{abstract} a 68 USD increase in 'net FDI inflows' and an increase in one USD from him increases a 0.17 USD in FDI. Similarly, a one USD increase in net FDI inflows causes a 0.76 USD increase in income from international tourism. However, it has asserted no longrun relationship between these variables. Importantly, these findings help the government and policymakers formulate and implement the right policies and programs for the sustainable tourism development of Nepal.

Keywords: FDI, tourism development, causal-comparative research design, bidirectional relationship, sustainable tourism development of Nepal

\section{Introduction}

FDI poses a major element for the tourism development of an economy. It establishes a lasting interest in management control over an enterprise to a host country. Ownership of a minimum of 10 percent ordinary share or voting right in the enterprise, establishes the lasting interest (International Monetary Fund [IMF], 2000; as cited in Makoni, 2015 , p. 77). It catalyzes sustainable tourism development. Sustainable tourism development is the anticipated management of the needs of present tourists and host 
regions while protecting and enhancing opportunities for the future (United Nations World Tourism Organization [UNWTO], 1994; as cited in Scutariu et al., 2017). Further, the management envisages using all resources in such a way that economic, social, and aesthetic needs can be fulfilled while maintaining cultural integrity, essential ecological processes, biological diversity, and life (p. 1).

FDI plays a significant role in developing the tourism industry. It provides required capital for the industry (United Nations Conference on Trade and Development [UNCTAD], 2007; as cited in (Nunkoo \& Seetanah, 2018, p. 557). Furthermore, it facilitates to transfer of skills, knowledge, and production technique to the host country(s) (Khoshnevis Yazdi et al., 2017, p . 2; Blomström et al., 1999; Jacob \& Groizard, 2007; Markusen, 1995; Marrocu \& Paci, 2011; Williams \& Deslandes, 2008; as cited in Nunkoo \& Seetanah, 2018, p. 557). Due to this coherent, the tourism industry could increase the world's gross domestic production (GDP) by 3.6 percent in 2018 (World Tourism Organization [WTO], 2019, p. 4). Furthermore, tourism posed as the world's third-largest export category in 2019 (WTO, 2020, p. 4).

However, the FDI deficiencies pose incompatible tourism development in Asian developing countries, like Nepal. The insignificant net inflow of FDI in developing countries of Asia seems not to innovate modern tourism facilities and services such as rest houses, restaurants, historical tours, and entertainment centers (Khoshnevis Yazdi et al., 2017, p .2; UNCTAD, 2007; Tang et al., 2007; as cited in Khanh, 2020, p.1). In such a situation, the provision of transport infrastructure and the construction of hotels and airports relies on FDI (Nunkoo \&
Seetanah, 2018, p. 557). This sort of capital deficiency for tourism modernization prevails in Nepal distinctly.

Furthermore, Nepal responded late to tourism as a potential economic sector for economic development attracting FDI. Five years plans of Nepal shadowed priority on tourism at the beginning (Basnyat, 2013, p. 1). Nepal's attempt for developing institutional and legal infrastructure to ease doing any business like tourism attracting FDI began in the 1980s (Nepal Rastra Bank [NRB], 2018, p. 11). As a result, she has had FDI stock worth of NRs. 182,919.6 million until mid-July 2019 (NRB, 2021, pp. 22-23) - a negligible sum.

Therefore, an analytic study of the contribution of FDI inflow to tourism development digs out a major path for the solution of capital deficiency in Nepal. Hence, this study sets specific objectives - to find out and discuss the causal relation of FDI inflow to tourism development in Nepal. Tourism receipts from international tourists and their arrivals proxy to tourism development in this study in course of finding a solution of capital deficiency for tourism.

\section{Literature Review}

\subsection{FDI Theories}

FDI theories have provoked FDI outflows from home countries and inflows to host countries for their competitive benefits. Among many FDI theories, the eclectic FDI theory developed by J. H. Dunning in 1981(referred to as the OLI paradigm) explains the international flows and FDI in terms of motives. Multinational enterprises (MNCs) have outflowed the FDI when they have had greater net benefits from host countries through ownership (O), location (L), and internalization (I) related advantages 
(Dunning \& Lundan, 2008; as cited in Adeola et al., 2020, p. 397). 'O' related advantages are firm-specific and exclusive to that firm, in the form of both: tangible and intangible assets such as trademarks, patents, information, and technology, which would result in production cost reductions (Hymer, 1976; Kindleberger, 1969; as cited in Makoni, 2015, p. 81). Further, these advantages have enabled the firm to accrue from 'market imperfections' theories on firm-specific and monopolistic advantages, respectively in a foreign country. In addition, Boddewyn (1985; as cited in Makoni, 2015) portrayed the relationship between OLI as,

Using ownership rights by the firm itself (internalization), rather than selling or leasing its ownership to other foreign firms through licensing or management contracts earns more profit. It is possible as the MNC firm exploits ' $\mathrm{O}$ ' and ' $\mathrm{I}$ ' related advantages through production, in collaboration with other firms outside its home country for additional input factors such as natural resources and human capital in the host country (L). The underpinning causes for the 'OLI' related benefits to the MNC's firm - the foreign markets serve through exports (in the location of the parent company) and local markets by domestic production to the local geography (p. 8).

The 'OLI' paradigm explains the underpinnings of MNCs for FDI outflows as well. Focusing on different aspects of it, the institutional FDI fitness theory developed by Wilhelms and Witter (1998) explains how the home country attracts more FDI. There, socio-cultural, education, market, and government pose as the pyramid of four FDI fitness institutes. The sociocultural block bases the pyramid because the rest of the institutions of the pyramid are derived and permeated from this institution.

Makoni (2015) has clarified how education the second block of the pyramid attracts FDI in the host country.

The educated human capital enhances research and development (R\&D) and information processing ability. At least, the actual level of education requires various skills needed to run the undertaken projects. The basic level of education might influence the productivity and efficiency of FDI operations, making formative skills such as the ability to speak, hear, understand, interpret and implement the key instructions for attracting FDI (p. 80).

Makoni (2015) has also explained how the market of the host country attracts FDI.

Market - the third block accounts for the economic and financial aspects of institutional FDI fitness. It does so in the form of machinery (physical capital) and credit (financial capital). Hence, developed and well-functioning financial markets in the host country are prominent features of the host country for attracting FDI (p. 80).

It is because, the market fitness theory, maybe postulated that open competitive markets with protective regulation attract more FDI than markets subjected to directive regulation (Wilhelms \& Witter, 1998, p. 4).

"Finally, government reigns over the other FDI Fitness Institutions: sociocultural, education, and markets. Investors, therefore focus on government as the primary source for actions and policies shaping FDI" (Wilhelms \& Witter, 1998, p. 4). 
Therefore, to the investors, government fitness refers to economic openness, a low degree of trade and exchange rate intervention, low corruption, and greater transparency (Popovici \& Calin, 2014 p. 17). Concisely, "the more the government does to provide an economic, legal, and infrastructure framework conducive to FDI, the more FDI it will obtain" (Wilhelms \& Witter, 1998, p. 38). Makoni (2015, p. 80) has concluded that although the pyramid is represented in a specific order, the four institutional blocks are interrelated and interact in unison in different forms.

\subsection{Tourism Development Theories}

Subsection-2.1hints that the competitive benefits stand as catalysts to the host country and the MNCs changing in FDI inflows and outflows for the tourism development. The incubation of the benefits from FDI links 'sustainable tourism development' (see its meaning in section-1, first paragraph) of an economy. In terms of fields, this tourism development refers to a multidisciplinary activity overlapping several economic sectors and employing a variety of human skillsets (Telce \& Schroenn, 2006; as cited in Adeola, et al., 2020, p. 396). It requires high capital injections for infrastructure, skilled labor, international marketing, and supply chain development (Jones, 1999; as cited in Adeola, et al., 2020, p. 397). Therefore, FDI is essential for assuring a skilled labor force, dependable physical infrastructure (roads, air transport, electricity, and water), and reliable communication services (telecom and internet connectivity) (Samimi et al., 2013, p. 60 ) for the sustainable tourism development.

\subsection{Relation between FDI and Tourism Development}

FDI and tourism development relate to each other. Several empirical studies explain the mechanism using FDI to tourism development and its importance in placing destinations on the tourism map, introducing foreign brands that improve the image of locations, and developing infrastructures such as motorways, airports, and hotels (UNCTAD, 2007; as cited in Adeola, et al., 2020, p. 397). Some of these studies have revealed a unidirectional relation, from tourism development to FDI on one hand, and on the other hand, some other studies have revealed the relation from FDI to tourism development. The rest of them have revealed either bidirectional or no causal relation between the FDI and tourism development.

\subsubsection{Unilateral Relation: FDI to Tourism Development}

The researchers found a positive relationship between FDI and tourism development mostly. The study of Tang et al. (2007; as cited in Khanh, 2020, p. 2) found a positive relationship in China using time series data. Sanford and Dong (2000; as cited in Khanh, 2020 , p. 2) in the case of the United States, Garcia-Flores et al. (2008; as cited in Khanh, 2020 , p. 2) in the case of Mexico, and Selvanathan et al. (2009, p. 23) in case of India found the similar relation. On the contrary of the positive relation, Khanh (2020, p. 5) during the period over 2003-2017 in Vietnam investigated a slightly negative relation of FDI to tourism development in both: the short-run and long-run. We have discussed the reasons behind this type of relation in section 1 .

\subsubsection{Unidirectional Relation: Tourism Development to FDI}

Contrasting to unidirectional relation from FDI to tourism development, some studies have found causality from tourism to FDI. 
Tourism sector development attracted FDI in countries such as India, China, Pakistan, Russia, Malaysia, Thailand, Hong Kong, etc. (Tiwari, 2011; as cited in Amin et al., p. 112). Katircioglu (2011; as cited in Nunkoo \& Seetanah, 2018, p. 561) has found a causal relationship between international tourism and FDI in the case of Turkey using dynamic time series analysis.

Strong reasons pose for the unidirectional relation from FDI to tourism development. The existing provision of goods and services in many developing countries needs more FDI for tourism products, capital, infrastructure, production techniques, and workforce (Nunkoo \& Seetanah, 2018, p. 562). These developing economies, therefore require more FDI on the one hand, and on the other hand, international hotel chains attract more investment in these countries due to the prospects of growing tourism demand in these economies (Tang et al., 2007; as cited in Nunkoo \& Seetanah, 2018). The authors further argued that in such situations, the international investors (the then tourists) match their ability to capitalize on the FDI in the developing economies. Additionally, they have the opportunity to obtain 'firsthand knowledge' and 'ground information' of the environment of the host countries for economic and business the FDI inflows

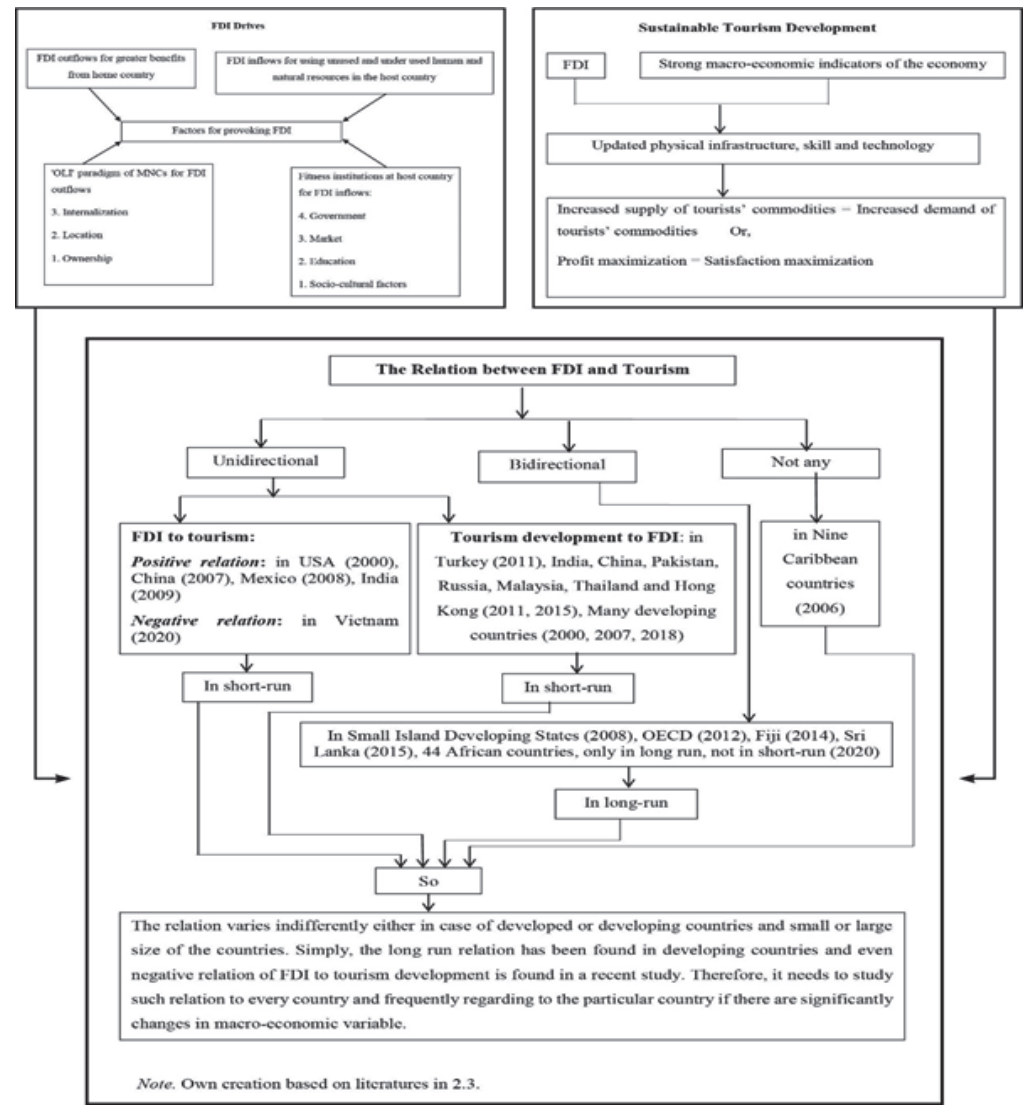

Chart 1

Conceptual Framework 


\subsubsection{Bidirectional Relation between FDI and Tourism Development}

Empirical studies portray bidirectional relation between FDI and tourism development mainly in Island and OECD countries. Craigwell and Moore (2008; as cited in Amin et al., 2020, pp. 112-113) have investigated a bidirectional causal relation between FDI and tourism in Small Island Developing States. Mustafa (2015, p. 81) has underscored the same type of relationship in the case of Sri Lanka. Using the co-integration technique, Jayaraman et al.'s (2014, p. 1361) study, has identified the positive long-run associations between FDI and tourism earnings in Fiji. Adeola et al. (2020, pp. 404405) also have asserted a long-run relation between FDI and tourism development, in the case of 44 African countries. The study of Fereidouni and Al-mulali $(2012$, p. 8) also has portrayed the long-run and short-run empirical link between FDI in the real estate sector and international tourism flows for selected OECD countries.

\subsubsection{No Relation between FDI and Tourism Development}

In contrast to the discussion in 2.3.1 to 2.3.3, few empirical studies stand on 'no relation between FDI and tourism development. Willem te Velde, \& Nair (2006, p. 450) have found no link between FDI and tourism development using panel regression analysis for the case of nine Caribbean countries.

\section{Conceptual Framework}

On the basis of section-2, chart- 1 depicts the conceptual framework of the relation between FDI inflows and tourism development.

\section{Research Gap}

The literature review has exposed that there is unidirectional causal relation from FDI to tourism development and tourism development to FDI indifferently either in the case of developed or developing countries and small or large size countries. We have also seen a bidirectional relationship between the variables in these countries. Even we have acknowledged no causal relation - neither from FDI to tourism development nor from tourism development to FDI. Furthermore, we have noticed the negative relation of FDI to tourism development in a few empirical studies. However, generally, the long-run relation has posed in developing countries with a degree of variability. We see the change in the relationship of the same country as well. Therefore, the empirical findings on the relation between FDI and tourism development are not conclusive. In such a situation, there is a need for further research on the topic (Nunkoo \& Seetanah, 2018, p.563) regarding each country in one hand. On the other hand, no one has made an empirical study upon "The relation between net FDI inflow and tourism development in Nepal" yet (so far, to my knowledge). Therefore, for the formulation and implementation of policies for tourism development in Nepal competitively, we have to study scientifically upon this issue.

\section{Methodology}

This study has followed the causalcomparative research design. It has asserted the dependent variable: 'net FDI inflow' and independent variable: 'tourism development' (its proxies: 'international tourism income', and 'number of international tourist arrivals in Nepal) first, and then interchanged the dependent into independent and independent 
into dependent one to investigate the relation between the independent and dependent variables. This research has deployed the time-series data of Nepal from 1995 to 2019 from the world development indicators of the World Bank to measure the relation (World Bank [WB], 2021). It has tested Unit root applying the Dickey-Fuller (DF), Augmented Dickey-Fuller (ADF), and Phillips Perron (PP) tests for cleaning the data. Then, it has performed regression analysis, and Engle and Granger cointegration tests. Finally, it has deployed Jacque-Bera, correlogram, and Breusch-Pagan-Godfrey tests to verify the results.

I have developed the following econometric models considering the variables being discoursed and calculated the short-run relation between the variables using Stata software.

FDI_NET_INFLOWS $=\alpha \neg 1+\mathrm{b} 1 \mathrm{INTL}$ TOURISM_INCOME+b2INTL_TOURIST_

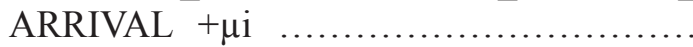

$\mathrm{Eq}(1)$

INTL_TOURISM_INCOME $=\alpha 2+\mathrm{b} 3 F D I$ NET_INFLOWS $+\mu \mathrm{i}$

$\mathrm{Eq}(2)$

INTL_TOURIST_ARRIVAL $=\alpha 3+b 4 F D I$

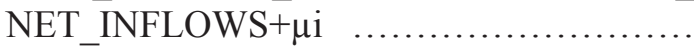
$\mathrm{Eq}(3)$

Similarly, I have developed the following econometric models for long-run analysis using EViews software.

FDI_NET_INFLOWS $=\beta \_0+\quad \beta \_1 \quad$ INTL TOURISM_INCOME $+\varepsilon_{-} \mathrm{t} 1$

$\mathrm{Eq}(4)$
INTL_TOURISM_INCOME $=\beta \_0+\beta \_1$ FDI_NET_INFLOWS $+\varepsilon_{-}$t 2

$\mathrm{Eq}(\overline{5})$

$\varepsilon_{-}(\mathrm{t} 1=\quad) \quad$ FDI_NET_INFLOWS$\beta \_0-\beta \_1 \quad$ INTL_TOURISM_INCOME Eq (6)

$\varepsilon_{-} \mathrm{t} 2=\mathrm{INTL}$ TOURISM_INCOME $-\beta \_0-\beta \_1$ FDI_NET_INFLOWS ................ $\mathrm{Eq}(\overline{7})$

$(\mathrm{t}-1)=\mathrm{FDI}$ NET_INFLOWS- $\beta \_0-\beta \_1$

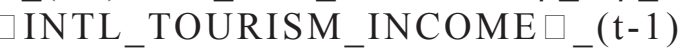
$\mathrm{Eq}(8)$

$\square$ (t-1)=INTL_TOURISM_INCOME$\beta \_0-\beta \_1 \quad \square$ FDI_NET_INFLOWS $\square$ (t-1) $\mathrm{Eq}(9)$

$\Delta$ FDI_NET_INFLOWS $=\beta \_0+\beta \_1 \Delta \mathrm{INTL}$ TOURISM_INCOME $+\beta \_2 \square(\mathrm{t}-1)+\mathrm{v}_{-} \mathrm{t} \ldots$ Eq (10) $\triangle$ INTL_TOURISM_INCOME $=$ $\beta \_0+\beta \_1 \quad \Delta$ FDI_NET_INFLOWS $+\beta \_2$ $(\mathrm{t}-1)+\mathrm{v}_{-} \mathrm{t} \quad \ldots$. Eq (11)

Where,

INTL_TOURIST_ARRIVAL $=$ Number of international tourist arrival; FDI_NET_ INFLOWS $=$ foreign direct investment net inflows (USD); and INTL_TOURISM INCOME $=$ tourism income frominternational tourists (USD). Similarly, $\mu \mathrm{i}=$ Error term; $\alpha 1, \alpha 2 \& \alpha 3=$ Constant terms; and b1, b2, b3 \& b4 = Coefficients in short-run. Finally, $\mathrm{B} 0=$ Constant terms; $\beta 1$ and $\beta 2=$ Coefficient of the respective variable; $\square \mathrm{t}-1=$ Error terms of previous year; $\square \mathrm{t} 1$ and $\square \mathrm{t} 2=$ Error terms; and $\mathrm{Vt}=$ Transformed error terms in long run. 


\section{Figure1}

Multiple Line Graph of Net FDI Inflows, International Tourism Income, and Tourist Arrivals in Nepal, $1995-2019$

fdi_net_inflows
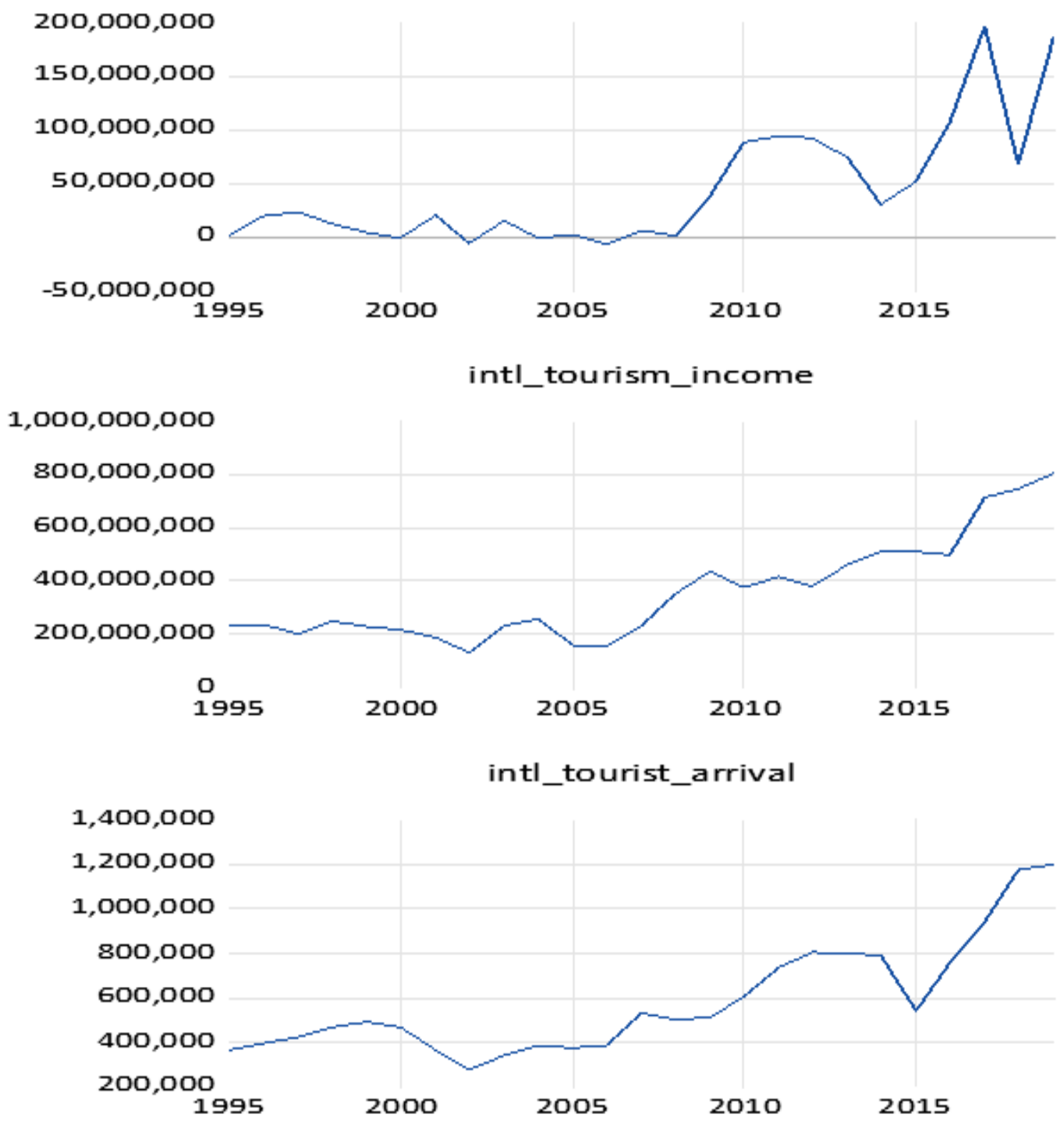

Note. Constructed by the author using EViews for stationary checking 


\section{Result and Discussion}

\subsection{Stationary Checking}

Stationary checking for confirming the stationary data to proceed for statistical analysis prevents spurious regression analysis. 'Tending the average value of time series to revert to its long-run average value and properties of data series are not affected by the change in time only' is the condition for stationary data series (Shrestha \& Bhatta, 2018). Generally, we start stationarity checking by examining the properties of a series of data graphically and then confirm it statistically (pp. 72-73).

The graphic presentation in figure-1 has depicted all three series of the variables are nonstationary at the level. Therefore, I have followed the three common unit root techniques- DF, ADF, and PP for confirming whether the variables of interest are stationary and presented their results in table 1 below.

Table 1

Unit Root Test Results of the Variables at Level

\begin{tabular}{|l|l|l|l|l|l|l|}
\hline \multirow{2}{*}{ Unit root test at level variables } & \multicolumn{3}{|l|}{ Test with constant } & \multicolumn{3}{l|}{ Test with constant and trend } \\
\cline { 2 - 8 } & DF & ADF & PP & DF & ADF & PP \\
\hline FDI_NET_INFLOWS & -0.60 & -0.49 & -0.98 & $-3.46^{* *}$ & -3.23 & -3.15 \\
\hline INTL_TOURISM_INCOME & 0.51 & 0.73 & 1.99 & -1.62 & -1.43 & -0.96 \\
\hline INTL_TOURIST_ARRIVAL & 0.29 & 0.40 & 0.25 & -2.27 & -1.89 & -1.25 \\
\hline Critical value at 5\% & -1.956 & -2.992 & -2.992 & -3.190 & -3.612 & -3.612 \\
\hline
\end{tabular}

Unit Root Test Results of the Variables at First Difference

\begin{tabular}{|l|l|l|l|l|l|l|}
\hline \multirow{2}{*}{ Variables } & \multicolumn{3}{l|}{ Test with constant } & \multicolumn{3}{l|}{ Test with constant and trend } \\
\cline { 2 - 7 } & $\mathrm{DF}$ & $\mathrm{ADF}$ & $\mathrm{PP}$ & $\mathrm{DF}$ & $\mathrm{ADF}$ & $\mathrm{PP}$ \\
\hline FDI_NET_INFLOWS & $-6.45 * * *$ & $-7.14 * * *$ & $-7.28 * * *$ & $-7.11 * * *$ & $-7.12 * * *$ & $-10.54 * * *$ \\
\hline $\begin{array}{l}\text { I N T L_T O U R I S M } \\
\text { INCOME }\end{array}$ & $-4.69 * * *$ & $-4.60 * * *$ & $-4.61 * * *$ & $-5.45 * * *$ & $-5.22 * * *$ & $-10.15 * * *$ \\
\hline $\begin{array}{l}\text { I N T L_T O U R I S T_- } \\
\text { ARRIVAL }\end{array}$ & $-4.00 * * *$ & $-3.91 * * *$ & $-3.92 * * *$ & $-4.33 * * *$ & $-4.16 * * *$ & $-4.14 * *$ \\
\hline Critical value at 5\% & -1.956 & -2.998 & -2.998 & -3.190 & -3.622 & -3.622 \\
\hline
\end{tabular}

\subsection{Short-Run Relationship}

We have measured the short-run relation between 'net FDI inflows' and 'tourism development' using Eq. (1) formulated in the methodology section. Table-2 portrays the result of the measurement, which is significant at a 90 percent level of confidence. Here, proxies for tourism development are 'international tourism income' and 'international tourist arrivals. The result shows that an increase in 1 USD from international tourism results in a 0.17 USD increase in 
'net FDI inflows' and the increase in one person tourist arrival increases 67.6 USD in 'net FDI inflows' in Nepal.

\section{Table 2}

\section{Linear Regression Result: Tourism Development to FDI}

\begin{tabular}{|l|l|l|l|}
\hline Dependent variable: FDI_NET_INFLOWS & Coefficient & p-value & Sig \\
\hline INTL_TOURIST_ARRIVAL & 67.566 & 0.081 & $*$ \\
\hline INTL_TOURISM_INCOME & 0.165 & 0.076 & $*$ \\
\hline Constant & 53729256 & 0.011 & $* *$ \\
\hline $\begin{array}{l}\text { R-squared } \\
\text { Number of observations } 25\end{array}$ & & & \\
\hline
\end{tabular}

$* * * p<0.01, * * p<0.05, * p<0.1$

Source: Own computation using Stata

Similarly, we have measured the short-run relation between tourism development (proxy: 'international tourism income') to 'net FDI inflows' using Eq. (2) and presented its result in table-3. The result shows that a 1 USD increase in 'net FDI inflows' causes a 0.76 USD increase in tourism income in Nepal from international tourism.

\section{Table 3}

Linear Regression Result: FDI to Tourism Development (Proxy: Tourism Income)

\begin{tabular}{|l|l|l|l|}
\hline Dependent variable: INTL_TOURISM_INCOME & Coefficient & p-value & Sig \\
\hline INTL_TOURIST_ARRIVAL & 557.843 & 0.000 & $* * *$ \\
\hline FDI_NET_INFLOWS & 0.761 & 0.089 & $*$ \\
\hline Constant & -2056977 & 0.963 & \\
\hline $\begin{array}{l}\text { R-squared } \\
\text { Number of observations 25 }\end{array}$ & & & \\
\hline
\end{tabular}

$* * * p<0.01, * * p<0.05, * p<0.1$

Source: Own computation using Stata

Finally, the result of the short-run relation between 'tourism development' (proxy: 'international tourist arrival') to 'net FDI inflows' as per Eq. (3) is presented in table-4. This relation is not statistically significant, which infers the relation between 'tourism developments' to 'net FDI inflows' in Nepal cannot be established significantly in the short run. 


\section{Table 4}

Linear Regression Result: FDI to Tourism Development (Proxy: Tourist arrivals)

\begin{tabular}{|l|l|l|l|}
\hline $\begin{array}{l}\text { Dependent variable: INTL_TOURIST_ } \\
\text { ARRIVAL Coefficient }\end{array}$ & p-value & Sig \\
\hline INTL_TOURISM_INCOME & 0.001 & 0.000 & $* * *$ \\
\hline FDI_NET_INFLOWS & 0.001 & 0.342 & \\
\hline Constant & 167010.67 & 0.003 & $* * *$ \\
\hline $\begin{array}{l}\text { R-squared } \\
\text { Number of observations } 25\end{array}$ & \\
$* * * p<0.01, * * p<0.05, * p<0.1$ &
\end{tabular}

Source: Own computation using Stata

The short-run change in the differenced form of time series might miss the long-run information (Shrestha and Bhatta, 2018, p. 77). Therefore, we have to use another model to analyze the long-run relation.

\subsection{Long-Run Relationship}

\section{Engle and Granger 2 Steps Test}

This study has used the cointegration method for finding the long-run relation between time series variables. If there is at least a linear combination of integrated variables, these series are stationary and, in such cases, these variables are cointegrated in the long run. It means that there could be a long-run relationship among the stationary series of variables.

Most of the macro-economic variables are not integrated into levels - 'I (0)' but integrated into the first difference - 'I (1)'. Our testing variables 'net FDI inflows', 'international tourism income', and 'international tourist arrival' also follow it. When all these variables are stationary at I (1), we have to use the 'Engle and Granger 2 steps method' of cointegration for finding their long-run relation. Here, I have used 'international tourism income' only as of the proxy of tourism development for the long-run analysis because, in the short-run relation measurement between tourism development (taking 'international tourism arrival' as a proxy) and 'net FDI inflows', have appeared insignificant up to 90 percent level of confidence.

As per the first step of the 'Engle and Granger 2 steps method', I have designed Eq. (4) and Eq. (5) as the long-run equilibrium model of variables: 'net FDI inflows' and 'international tourism income', to run the OLS methods. There, $\beta_{\mathrm{i}}=$ constant terms to be estimated, and as per the theories based on the literature review; $\beta_{1}>0$ and $\beta_{2}>0$ except in the case of Vietnam (2020). Table-5 below portrays the result of Eq. (4) and Eq. (5) 
Table 5

Long Run Relationship between Net FDI Inflows and Tourism Development

\begin{tabular}{|c|c|c|c|c|}
\hline \multicolumn{2}{|l|}{ Variables } & \multicolumn{3}{|l|}{ Results } \\
\hline Dependent & Independent & Coefficient & Prob. & R Square \\
\hline \multirow{2}{*}{ FDI_NET_INFLOWS } & INTL_TOURISM_INCOME & 0.268066 & 0.0000 & \multirow{2}{*}{0.69} \\
\hline & $\mathrm{C}$ & -49106526 & 0.0005 & \\
\hline \multicolumn{4}{|c|}{$\begin{array}{l}\text { INTL_TOURISM_INCOME } \\
\text { FDI_NET_INFLOWS } \\
3.472443 \\
0.0000\end{array}$} & \multirow[t]{2}{*}{0.65} \\
\hline & $\mathrm{C}$ & $2.00 \mathrm{E}+08$ & 0.0000 & \\
\hline
\end{tabular}

Note, Own computation using EViews

Table 5 has portrayed the significant result of the constant and independent variable: 'international tourism income', as their probabilities are 0.0005 and 0.0000 respectively. Similarly, R-squared indicates that $69 \%$ of the variation in 'international tourism income' is explained by the linear relationship with 'net FDI inflows'. Likewise, there is a very significant probability result: 0.0000 for both: constant and independent variables: 'net FDI inflows' and $65 \%$ of the variation in 'net FDI inflows' is explained by the linear relationship with 'international tourism income'.

However, these regression results could be spurious, so these variables might have no long relation between them if their residual series are not stationary. Therefore, this discourse has proceeded with stationarity checking of the residuals applying the ADF unit root test. For finding out the stationarity of residual terms: from the regression, Eq. (4) and Eq. (5) are conversed into Eq. (6) and Eq. (7). Here, the calculated value reported in the ADF test is valid but its statistics are not valid for the residual unit root test because residuals are hidden (D'Amica, 2021) instate its statistics (critical values) are as mentioned in table-6 (Engle \& Yoo, 1987, p. 157). The set null hypothesis: $H_{0}$ for this purpose is "Series are not cointegrated". Therefore, rejecting $\mathrm{H}_{0}$ results in our series is stationary and there is a long-run relation between 'tourism development' and 'net FDI inflows'. 


\section{Table 6}

ADF Unit Root Test Results of the Residuals at Level

\begin{tabular}{|c|c|c|c|c|c|c|c|c|}
\hline \multirow{2}{*}{$\begin{array}{l}\text { Independent } \\
\text { variable }\end{array}$} & \multirow{2}{*}{$\begin{array}{c}\text { Null } \\
\text { hypothesis }\end{array}$} & \multirow{2}{*}{$\begin{array}{c}\text { Calculated } \\
\text { values }\end{array}$} & \multirow{2}{*}{$\begin{array}{c}\text { Number of } \\
\text { variables }\end{array}$} & \multirow{2}{*}{$\begin{array}{l}\text { Sample } \\
\text { size }\end{array}$} & \multicolumn{3}{|c|}{ Critical values } & \multirow{2}{*}{ Result } \\
\hline & & & & & $10 \%$ & $5 \%$ & $1 \%$ & \\
\hline $\begin{array}{c}\text { INTL_- } \\
\text { TOURISM } \\
\text { INCOME }\end{array}$ & $\begin{array}{c}\text { Residual_1t } \\
\text { has a unit } \\
\text { root }\end{array}$ & 7.2863 & 2 & $24<50$ & 3.28 & 3.67 & 4.32 & $\begin{array}{l}\text { Residual_tt is } \\
\text { stationary at level } \\
\text { with no trend and } \\
\text { intercept at } 1 \% \\
\text { critical value }\end{array}$ \\
\hline $\begin{array}{l}\text { FDI_NET_} \\
\text { INFLOWS }\end{array}$ & $\begin{array}{c}\text { Residual_ } \\
\text { 1t has a } \\
\text { unit root }\end{array}$ & -3.7178 & 2 & $24<50$ & 3.28 & 3.67 & 4.32 & $\begin{array}{l}\text { Residual_lt is } \\
\text { stationary at level } \\
\text { with no trend and } \\
\text { intercept at } 5 \% \\
\text { critical value }\end{array}$ \\
\hline
\end{tabular}

Note, Own computation using EViews

This stationarity test result of table- 6 has portrayed that $\square_{t 1}$ and $\square_{t 2}$ are stationary in the regression of Eq. (6) and Eq. (7) at the level. Therefore, we can proceed to the second step in course of confirming the long-run relation.

\section{Error Correction Models (ECMs) Test}

After establishing the long-run relation between tourism development and 'net FDI inflows', the second step is an estimation of the Error Correction Models (ECMs). We have to estimate ECMs to determine the short-run dynamic behavior of 'net FDI inflows' to 'tourism development' and 'tourism development' to 'net FDI inflows' in Nepal. This discourse has designed Eq. (8) and Eq. (9) to estimate the ECMs. These short-run models need to be in indifference-stationary like, $\triangle F D I \_N E T \_I N F L O W S=\beta \_0+\beta \_1 \quad \Delta I N T L \_T O U R I S M \_I N C O M E+\beta \_2 \square \_(\mathrm{t}-1)+\mathrm{v} \_\mathrm{t} \ldots \mathrm{Eq}$. (10) and ECT

$\Delta \mathrm{INTL} \_T O U R I S M \_I N C O M E=\beta \_0+\beta \_1 \Delta$ FDI_NET_INFLOWS $+\beta \_2 \square \_(\mathrm{t}-1)+v_{-}$t ECT ...Eq. (11)

Here, $\beta_{2}=$ Error correction term estimated coefficient, where $-1<\beta_{2}<0$.

$\mathrm{ECT}=$ Error Correction term and each of the other terms in these equations are similar as defined in the methodology section. 
Table-7 has revealed the value of $\beta_{2 \text { or }}$ ECT of D (INTL_TOURISM_INCOME) RESIDUAL_ LT (-1) is -1.049 which is significant (p-value: 0.0001). However, this result for short-term dynamics has crossed the range: $-1<\beta_{2}<0$. Therefore, we have to infer that there is no long-run relationship between 'net FDI inflows' and 'tourism development'. Rather more, the long-run disequilibrium can be corrected within a unit of time series that is one year in this case. This period is short-run itself. Similarly, $\beta_{2}$ or D(FDI_NET_INFLOWS) RESIDUAL_INC(-1) of independent variable: 'net FDI inflows' is -0.196 which is not significant (p-value: 0.2557$)$. We have to infer from this as well that there is no long-run relation between 'tourism developments' and 'net FDI inflows'.

\section{Table 7}

Error Correction Result Using Least Square Method

\begin{tabular}{|l|l|l|l|}
\hline Variables & Results \\
\hline Dependent & Independent & Coefficient & Prob. \\
\hline \multirow{2}{*}{ D(FDI_NET_INFLOWS) } & D(INTL_TOURISM_INCOME) & 0.2259 & 0.0371 \\
& RESIDUAL_LT(-1) & -1.0494 & 0.0001 \\
\hline \multirow{2}{*}{ D(INTL_TOURISM_INCOME) } & D(FDI_NET_INFLOWS) & 0.6031 & 0.1318 \\
& RESIDUAL_INC(-1) & -0.1961 & 0.2557 \\
\hline
\end{tabular}

Source: Own computation using EViews

Now, we are in the stage of verifying our regression findings preceded. For testing normality this discourse has set, $\mathrm{H}_{0}=$ Residuals are normally distributed. As value of Jarque-Bera test is 0.7383 which p-value is $0.6913(>0.05), \mathrm{H}_{0}$ is not rejected. Similarly, as per the correlogram of INTL_TOURISM_INCOME presents Q-statistics: 1.0058, 1.8567, 2.2772, 2.9496, 5.8592, $6.0093,9.0962,9.1930,9.6438,12.587,12.806$ and 18.230 and their p-values $0.316,0.395$, $0.517,0.566,0.320,0.422,0.246,0.326,0.380,0.248,0.306$ and 0.109 respectively (each $\mathrm{p}$ value $>0.05$ ), there is no auto correlation. Values of AC (autocorrelation) and PAC (partial autocorrelation) also indicate significant result as all $\mathrm{p}$ values are greater than 0.05 . Similarly, conducting the Breusch-Pagan-Godfrey test setting $\mathrm{H}_{0}=$ Homoskedasticity, $\mathrm{H}_{0}$ is not rejected as coefficient: -9396089, standard error: 11422131 and t-statistics: -0.822621 are valid being $p$ value: $0.4200(>0.05)$.

\section{Conclusion and Recommendations}

\subsection{Conclusion}

This study has accounted for the eclectic theory of FDI which has evoked strengthening four blocks of the institutional pyramid: socio-cultural factors, education, market, and government to attract an ample amount of FDI for tourism development in a country like Nepal. It has found the bidirectional relationship between 'net FDI inflows' and 'tourism development' in the short-run. The arrival of 100 international tourists causes a 6800 USD increase in 'net FDI inflows' and an increase in 100 USD from international tourism increases a 17 USD in FDI. Similar to the findings of Sanford and Dong (2000; as cited in Nunkoo \& Seetanah, 2018, 
p. 562), the opportunity to obtain 'firsthand knowledge' and ground information of the economic and business environment of Nepal to the then tourists who are potential investors in the tourism might be the underpinning of this relation: 'tourism development' to 'net FDI inflows. Similarly, a 100 USD increase in net FDI inflows causes a 76 USD increase in income from international tourism. Insufficient positive macro-level determinants could be the cause of this result. The bilateral long-run relation between tourism development and the FDI net inflows has been proved in the first step of Engle and Granger's 2 steps method of cointegration. Nevertheless, in the second step: the error correction model has not been passed. It shows no longer duration than one year is required for the correction of long-run disequilibrium by the short-run dynamics: the error correction term in case of the relations from tourism development to FDI net inflows. The relationship from FDI net inflows to tourism development is insignificant. Therefore, it has inferred no significant long-run relationship between these variables based on data: 1995 to 2019 and methods used in this study.

\subsection{Recommendations}

The foci of Nepal require strengthening four blocks of the institutional pyramid of FDI fitness theory to attract an ample amount of FDI for its tourism development. Formulation of the constitution of Nepal 2072 has managed common understanding and cooperation within the parties and political stability (Ja. Ba. Ra. et al p. 95). We have to make other efforts for having the government of Nepal (GoN) as the custodian of its people, tourists, and resources to accelerate tourism development. If we determine not to waste food, cloth, and other means at least and instead transfer these commodities to the needy people with honors, it helps improve the second block; the sociocultural block reducing the shabby presence of poor people in front of tourists. Estimating the required workforce for the tourism industry, the education sector has to provide pieces of training for supplying the workforce in the short run and manage formal education to supply the estimated workforce in the long run. We have to protect our natural and cultural heritages and brand them in the tourism market to strengthen the fourth blocks market. Building the strong institutional pyramid of the four blocks, we can wage an ample amount of FDI for our tourism development.

There is a need to combine efforts of publicprivate partnership for managing the FDI to accelerate tourism development. Local communities have to organize themselves to undertake planning and management (Asker et al., 2010; as cited in Moyo \& Tichaawa, p. 4) for tourism development. The private sector has to begin fostering sustainability for tourism development by collaborating with government agencies and other accountable organizations (Moyo \& Tichaawa, 2017, p. 10). As the lead partner for pooling expertise and resources, the GoN has to encourage the private sector, communities, and academics/universities to enhance innovation and opportunities for tourism development. The government has to lead other stakeholders to develop and disseminate innovations for the knowledge economy - real competitive advantages that reside in information, knowledge, and human skills using computer and internet led technologies - through the better use of research base intelligence (OECD, 2010, pp. 64-66). It has to involve the communities 
in all steps of management for tourism development towards achieving sustainable development (Moyo \& Tichaawa, 2017, p. 10). Further, it has to create opportunities and projects aiming at community members more involved either through traveling or through entrepreneurism. Similarly, it has to encourage the communities and the private sector to extract maximum economic and social benefits from the tourism sector highlighting the impact of globalization on tourism demand, transport, information, and vulnerability to external shocks. Adding agro-tourism with every other tourism including business tourism, adventure tourism, wildlife tourism, wellness tourism, pilgrimage and spiritual tourism, cultural tourism, and so on help to sustain tourism even during pandemic like Covid- 19. These attempts of tourism development supporting biodiversity conservation initiatives and livelihood development strategies would create sustainable tourism development in Nepal.

\section{References}

Adeola, O., Boso, N., Osabutey, E. C., \& Evan, O. (2020). Foreign direct investment and tourism development in Africa. Tourism Analysis, 25(4), 395-408. https://doi.org/10.3727/1083 $54220 \times 15957702910144$

Amin, S., Al Kabir, F., Nihad, A., \& Khan, F. (2020). An empirical investigation between foreign direct investment (FDI) and tourism in Bangladesh. Journal of Tourism Management Research, 7(1), 110-121. https://doi. org/10.18488/journal.31.2020.71.110.121

Basnyat, S. (2013). Eclectic paradigm and the analysis of FDI in tourism in Nepal. The Gaze: Journal of Tourism and Hospitality, 5, 69-82. https://doi.org/10.3126/gaze.v5i0.15111
D’Amico, J. (2021). You tube file. https://www. jdeconomics.com/cointegration-and-errorcorrection-model/

Engle, R. F., \& Yoo, B. S. (1987). Forecasting and testing in co-integrated system. Journal of Econometrics, 35(1), 143-159. https://doi. org/10.1016/0304-4076(87)90085-6

Fereidouni, H. G., \& Al-mulali, U. (2012). The interaction between tourism and FDI in real estate in OECD countries. Current Issues in Tourism, 17(2), 1-9. https://doi.org/10.1080/1 3683500.2012 .733359

Ja. Ba. Ra., C. S., Karki, D., Khadka, M., Khatiwoda, I., \& Bhattarai, A. (2021). $t$. Supreme Court. faisala_supreme_0071.pdf supremecourt.gov.np.

Jayaraman, T. K., Chen, H., \& Bhatt, M. (2014). Research note: Contribution of foreign direct investment to the tourism sector in Fiji: An empirical study. Tourism Economics, 20(6), 1357-1362. https://doi.org/10.5367/ te. 2013.0358

Khanh, V. T. Van. (2020). Influence of foreign direct investment on tourism development: An evidence from Vietnam. Social and Economic Geography, 5(1), 1-6. https://doi. org/10.12691/seg-5-1-1

Khoshnevis Yazdi, S., Homa Salehi, K., \& Soheilzad, M. (2017). The relationship between tourism, foreign direct investment, and economic growth: Evidence from Iran. Current Issues in Tourism, 20(1), 15-26. https://doi.org/10.1080/13683500.2015.1046 820

Makoni, P. L. (2015). An extensive exploration of theories of foreign direct investment. Risk Governance and Control: Financial Markets and Institutions, 5(2), 77-83. 
Moyo, S., \& Tichaawa, T. M. (2017). Community involvement and participation in tourism development: A Zimbabwe study. African Journal of Hospitality, Tourism and Leisure, 6(1), 1-15. https://www.researchgate.net/ publication $/ 318542395$

Mustafa, A. M. M. (2015). Foreign direct investment in developing Sri Lanka"s tourism industry: Problems and prospects. Proceedings of the Third International Conference on Asian Studies, 75-84. www.theicrd.com

Nepal Rastra Bank. (2018). A survey report on foreign direct investment in Nepal. www.nrb. org.np

Nepal Rastra Bank. (2021). A survey report on foreign direct investment in Nepal (2018/19). www.nrb.org.np

Nunkoo, R., \& Seetanah, B. (2018). Foreign direct investment and tourism development: $A$ theoretical and empirical review (C. Cooper, S. Volo, W. C. Gartner, \& N. Scott (Eds.)). SAGE Publications Ltd.

Organization for Economic Co-Operation and Development. (2010). OECD tourism trends and policies 2010. In OECDpublishing. www. sourceoecd.org/9789264077416

Popovici, O. C., \& Călin, A. C. (2014). FDI theories. A location-based approach. The Romanian Economic Journal, 17(53), 1-23.

Samimi, A. J., Sadeghi, S., \& Sadeghi, S. (2013). The relationship between foreign direct investment and tourism development: Evidence from developing countries. Institutions and Economies, 5(2), 59-68.
Scutariu, A. L., Nastase, C., \& Popescu, M. (2017). Perspectives of sustainable development of tourism in the North-East Region of Romania. Sustainability, 9(1), 1-14. https://doi. org/10.3390/su9010056

Selvanathan, S., Selvanathan, \& E.A.Viswanathan, B. (2009). Causality between foreign direct investment and tourism: Empirical evidence from India. In Applied Economics (Vol. 17). https://doi.org/10.1080/00036840701367598

Shrestha, M. B., \& Bhatta, G. R. (2018). Selecting appropriate methodological framework for time series data analysis. Journal of Finance and Data Science, 4(2), 71-89. https://doi. org/10.1016/j.jfds.2017.11.001

te Velde, D. W., \& Nair, S. (2006). Foreign direct investment, services trade negotiations, and development: The case of tourism in the Caribbean. Development Policy Review, 24(4), 437-454. https://doi.org/10.1111/ j.1467-7679.2006.00333.x

Wilhelms, S. K. S., \& Witter, M. S. D. (1998). Foreign direct investment and its determinants in emerging economies, No. 20523-4600; Issue 9 ..

World Bank. (2021). World development indicators.

World Tourism Organization. (2019). International tourism highlights. In Unwto (2019th ed.). https://doi.org/10.18111/9789284421152

World Tourism Organization. (2020). International tourism highlights. In UNWTO (2020th ed.). https://doi.org/10.18111/9789284422456 